\title{
A hajas sejtes leukémia korszerú diagnosztikája és kezelése
}

\author{
Illyés Gabriella ${ }^{1,2}$, Timár Botond ${ }^{1,2}$, Bödör Csaba $^{1,2}$, Demeter Judit ${ }^{3}$, Nagy Noémi $^{1,2, @ ~}$ \\ ${ }^{1}$ HCEMM-SE Molekuláris Onkohematológia Kutatócsoport, Budapest \\ ${ }^{2} I$. Sz. Patológiai és Kísérleti Rákkutató Intézet, Semmelweis Egyetem, Budapest \\ ${ }^{3}$ Belgyógyászati és Onkológiai Klinika, Semmelweis Egyetem, Budapest
}

\begin{abstract}
A hajas sejtes leukémia (HCL) egy indolens lefolyású ritka B-sejtes lymphoma. Diagnosztikájában jellegzetes morfológiai képén túlmenően a sejtek felszínén megtalálható markerek azonosítása áramlási citometriával, valamint a betegségben előforduló specifikus fehérjék immunhisztokémiai detektálása jelenti a rutineljárást. Kiemelt szerepet tölt be a differenciáldiagnosztikában a $B R A F$ V600E mutációjának a kimutatása, melyre ma már számos módszer áll rendelkezésre, mint például az immunhisztokémia, pyroszekvenálás, allélspecifikus PCR vagy a droplet digitalis PCR. A tumorsejtek jelátviteli rendszerében és szabályozásában azonban a $B R A F$ mutációjának következtében kialakuló folyamatos aktivitása mellett egyéb mechanizmusok is szerepet játszhatnak, többek között növekedési faktorok, interleukinek, adhéziós fehérjék vagy éppen mikro-RNS-ek. A patomechanizmus egyre részletesebb megismerése érdekében egyéb daganatokhoz hasonlóan a HCL-ben is aktív kutatások folynak a genetikai háttér feltérképezésére új generációs szekvenálás segítségével. Leírtak már nagy százalékban előforduló mutációkat a $C D K N 1 B$-, KLF2- és KMT2C-gének esetében, továbbá egyéb génekben is alacsonyabb előfordulási aránnyal. Genetikailag, sőt klinikai manifesztáció és terápiás válasz alapján is jelentős eltérések láthatóak a klasszikus és variáns HCL-es betegek között, elkülönítésük épp ezért rendkívül fontos. Míg a klasszikus esetben első vonalban alkalmazott purin nukleozid analógok kiemelkedő válaszreakciót képesek kiváltani, a variáns HCL-es betegek gyakran refrakterek a kezelésre, és esetükben a célzott BRAF-gátlók szintén hatástalanok. Számos klinikai kutatás zajlik a jelenleg is alkalmazott terápiás szerek optimalizálása, kombinációban történő alkalmazása, valamint egyéb lymphoid daganatokban alkalmazott gyógyszerek és új támadáspontok ellen tervezett molekuláknak a HCL kezelésébe történő bevonása céljából.
\end{abstract}

Kulcsszavak: hajas sejtes leukémia, $B R A F$-mutáció, új generációs szekvenálás

\section{Hairy cell leukemia: diagnosis and treatment}

Hairy cell leukemia (HCL) is a rare indolent B-cell malignancy. In addition to characteristic morphology of HCL cells, the identification of the cellular surface markers and the expression of specific proteins by flow cytometry and immunohistochemistry are routine procedure in HCL diagnosis. Detection of BRAF V600E mutation plays key role in differential diagnosis of HCL which can be detected by several novel methods, such as immunohistochemistry, pyrosequencing, allele specific PCR or droplet digital PCR. Beside the BRAF mutation there can be other mechanisms causing constitutive activity in the signaling pathway and regulating the tumor cells such as growth factors, interleukins, adhesion proteins and micro-RNAs as well. Like in other malignancies, in order to clarify the pathomechanism, the genetic background of HCL is also actively investigated by next-generation sequencing. Frequent mutations were described in $C D K N 1 B, K L F 2$ and $K M T 2 C$ genes, moreover in other genes with lower incidence rate, as well. Genetically, and even in clinical manifestation and therapeutic response, significant differences can be found between patients with classical and variant HCL. While classical type has outstanding response for the first-line treatment with purine analogues, patients with variant HCL are often refractory to the treatment, and the BRAF inhibitors prove to be ineffective. Therefore, it is really important to distinguish these two entities. Several clinical studies are still in progress for the optimization and application of combining the currently applied therapeutic agents, furthermore other drugs that used in lymphoid malignancies are under investigation. New target molecules are also designed as novel therapeutic opportunity in HCL treatment.

Keywords: hairy cell leukemia, $B R A F$ mutation, next-generation sequencing

(Beérkezett: 2021. március 12.; elfogadva: 2021. május 16.)

\footnotetext{
@ Levelezési cím: Dr. Nagy Noémi, Semmelweis Egyetem, I. Sz. Patológiai és Kísérleti Rákkutató Intézet, 1085 Budapest, Üllői út 26. , Tel.: +36-1-215-7300/54473; E-mail: nagy.noemi@med.semmelweis-univ.hu
} 


\section{Rövidítések}

ADA - adenozin dezamináz; AJH - American Journal of Hematology; AKT - protein kináz B; ANXA1 - annexin A1; AR - androgén receptor; AS-PCR - allélspecifikus PCR; Bcl2 B-cell lymphoma 2; BRAF - Raf murin sarcoma virális onkogén homológ $\mathrm{B}$; $\mathrm{BRD} 4$ - bromodomént tartalmazó fehérje 4; BTK - Bruton tirozin kináz; CDKN1B (p27) - ciklindependens kinázinhibitor 1B; CEBPA - CCAAT enhancer kötőfehérje alfa; COVID-19 - koronavírus-betegség 2019; CR - komplett remisszió; CREBBP - CREB kötőfehérje; DBA44 - B-sejt centroblastellenes antitest; ddPCR - droplet digitális PCR; EP300 - adenovírus E1A-asszociált celluláris p300 transzkripciós koaktivátor fehérje; EPB4.IL2 - „erythrocyte protein band 4.1-like 2"; ERK - mitogénaktivált protein kináz; FDA - USA Élelmiszerbiztonsági és Gyógyszerészeti Hivatala; FGF - fibroblastnövekedési faktor; FGFR1 - fibroblastnövekedési faktorreceptor 1; FLT1 - fms-szerü tirozin kináz 1; FLT3 - fms-szerü tirozin kináz 3 receptor; Gas7 - „growth arrest-specific protein7"; GAP - GTP-áz-aktiváló fehérjék; GC - centrum germinativum; G-CSF - granulocyta kolóniastimuláló faktor; GRB2 - növekedési faktor receptorkötő fehérje 2; GDP/ GTP - guanozin difoszfát/trifoszfát; HCL - hajas sejtes leukémia; $I G H V$-gén - immunglobulin nehézlánc; IHC - immunhisztokémia; IL2R1 - interleukin-2 receptor 1; IL3R - interleukin-3 receptor; KLF2 - Krüppel-szerü faktor 2; KMT2C - lizin N-metiltranszferáz 2C; LMB-2 - anti-Tac(Fv)-PE38 immunotoxin; LST1 - leukocyta specifikus transzkriptum 1; MAPK - mitogénaktivált protein kináz; MAP2K1 - MAPK kináz 1; MED12 - RNS-polimeráz 2 transzkripció-mediátor 12. alegység homológ; MEK - mitogénaktiválta protein kináz; MPT - moxetumomab pasudotox; MRD - minimális reziduális betegség; NGS - új generációs szekvenálás; NOTCH - notch receptor; NRTK1 - neurotroph receptor tirozin kináz 1; OGYÉI - Országos Gyógyszerészeti és Élelmezés-egészségügyi Intézet; ORR - teljes válaszarány; PA - purin analógok; PAS perjódsav-Schiff-reakció; PCA-1 - plazmasejt-asszociált antigén $1 ; \mathrm{p}$-ERK1/2 - foszforilált mitogénaktivált protein kináz 1/2; PFS - medián progressziómentes túlélés; PI3K - foszfoinozit-3 kináz; PR - parciális remisszió; PTEN - foszfatáz és tenzin homológ; RAS - patkány sarcoma fehérje; RUNX1 RUNT homológiai domént hordozó transzkripciós faktor 1; SMZL - splenicus marginális zóna B-sejtes lymphoma; SOS guanin nukleotidkicserélő faktor; TIMP1,4 - metallopeptidáz-inhibitor 1,4; TKR - tirozin kináz receptor; TNFa - tumor nekrózisfaktor alfa; TRAP - tartarátrezisztens savanyú foszfatáz; VAF - variáns allélfrekvencia; VCAM1 - vascularis sejtadhéziós molekula 1; vHCL - variáns hajas sejtes leukémia; WHO - Egészségügyi Világszervezet

\section{Bevezetés}

\section{A hajas sejtes leukémia mint önálló entitás}

A hajas sejtes leukémia (HCL) egy ritka B-sejtes nonHodgkin-limfóma, amely a felnőttkori leukémiák csupán 2\%-át teszi ki [1]. 1958-ban a HCL-t pancytopeniával és splenomegaliával társuló indolens lefolyású malignus megbetegedésként írták le Bouroncle és munkatársai, akik ekkor elsőként karakterizálták a betegség klinikai és patológiai jellemzőit [2]. Az önálló haematológiai entitásként való besorolása ellenére B-sejtes eredete csupán az 1980as években tisztázódott, ugyanis vita tárgyát képezte a tumorsejteken megjelenő B-sejt és monocyta eredetre utaló markerek jelenléte, sőt még az aktivált T-sejtekre jellemző IL2R1 jelenlétérôl is beszámoltak. Emellett morfológiai megjelenése sem könnyítette meg eredetének meghatározását [3, 4].

A HCL nevét a jellegzetes morfológiai képéről, a fénymikroszkóp segítségével jól látható villosus citoplazmanyúlványokkal rendelkező B-sejtekről kapta (1. ábra) [5]. Génexpressziós profilvizsgálatok alátámasztották, hogy egyes citoszkeletális gének (pl.: Gas7, EPB4.1L2, LST1) emelkedett expressziót mutatnak a hajas sejtes leukémiás betegekben, különösen az F és $\beta$-aktinnal kölcsönhatásba lépő fehérjéket kódolók közül, melyek feltételezhetően a nyúlványok kialakításában vesznek részt, melyek által a tumorsejt nagyobb felületet biztosít a többi tumorsejthez és az extracelluláris mátrixhoz való kapcsolathoz [6, 7].

A HCL sejtek felszínén elhelyezkedő immunglobulin molekulákat kódoló gének vizsgálatával azonosításra került az $I G H V$-gén szomatikus hipermutációja, mely a $\mathrm{B}$-sejtes érési folyamatok végbemenetelét igazolja. Mindebből az következik, hogy a HCL sejtek centrum germinatívumban (GC) zajló érési folyamatokon már átesett, érett B-sejtekből eredeztethetőek. További fontos megállapítás, hogy más B-sejtes daganatokkal ellentétben a hajas sejtek felszínén nemcsak egyféle immunglobulinklón fejeződik ki, hanem több is, mindez arra utal, hogy a tumorsejtek az érési folyamat valamely pontjánál megrekedhettek. Más GC eredetű tumorokkal összehasonlítva viszont az intraklonális $I G H V$-heterogenitásuk jóval alacsonyabb [7-9]. Az aktivált B-sejtekre jellemző markerek azonosítása (többek között a PC-1 és PCA1) viszont bizonyítékul szolgált arra, hogy a HCL sejtek a kései, érett fejlődési fázisban lévő B-sejtekből származnak [10]. Génexpressziós profilvizsgálatok alapján, összevetve naiv és GC eredetû B-sejtek expressziós mintázatával, a hajas sejtek leginkább a memória B-sejtekhez való hasonlóságot mutatnak. Habár memória B-sejt eredetét a hajas sejtekben kifejeződő CD11c génjének emelkedett expressziója is alátámasztja, vannak olyan memóriasejt-markerek (pl.: CD27), amelyek a hajas sejteknek nem jellemzői. Ugyanakkor ezen markerek a sejtek malignus transzformációja során is elveszhettek $[7,11,12]$.

\section{HCL-variáns típusa}

A hajas sejtes leukémiavariáns (vHCL) az Egészségügyi Világszervezet (WHO) 2016-os klasszifikációja alapján a nem osztályozható splenicus B-sejtes limfómák/leukémiák csoportjába tartozó entitás, amelyet korábban (a 2008-as klasszifikáció alapján) még a hajas sejtes leukémiák mellett soroltak fel. Az elkülönítést egyrészt a morfológia és fenotípus-eltérések, másrészt a klinikai tulajdonságokban megfigyelhető különbségek, az eltérő progresszió és kezelésre adott válasz teszik indokolttá (1. táblázat). A variáns esetek kétszer gyorsabban progre- 


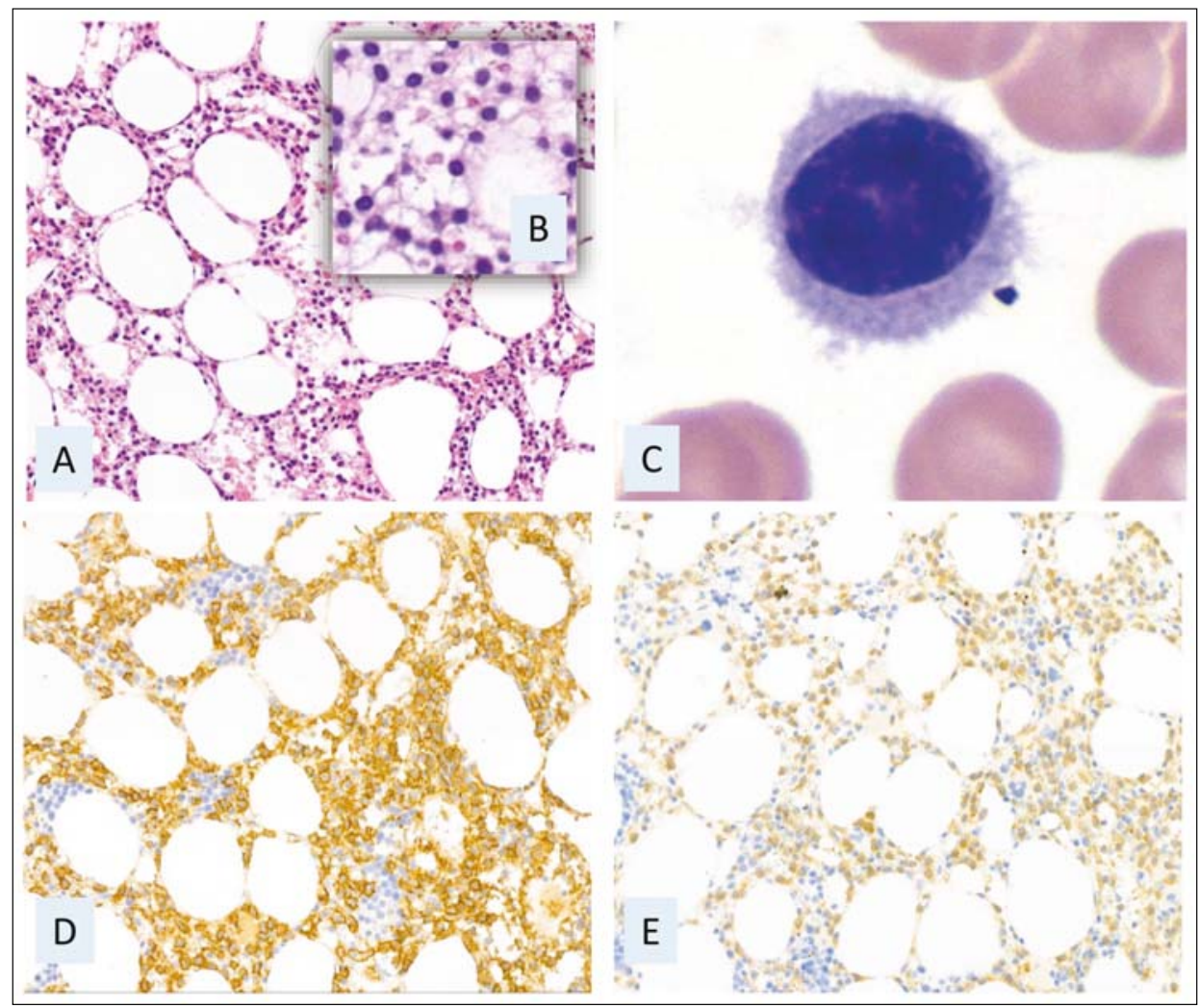

1. ábra. A HCL sejtek morfológiája. A) Az infiltrátum kezdetben a csontvelői zsírsejtek között, intersticiálisan jelenik meg, de itt is összefüggő mezőket alkot. B) A sejtekre jellemző a víztiszta, széles citoplazma a középen elhelyezkedő maggal, ami „tükörtojásra” emlékeztető képet mutat. C) A sejtmag kis lymphocytánál nagyobb, kerekded, ovoid és finoman rögös, homogén kromatineloszlású. A citoplazma széles, halvány basophil, körkörösen megjelenő változatos nyúlványokkal. D) A sejtek diffúz, homogén CD20-expressziót mutatnak. E) A BRAF V600E-ellenes antitesttel a sejtek citoplazmatikus pozitivitást mutatnak

diálnak a klasszikusoknál, és a cHCL-ben eredményesen alkalmazott purin nukleozid analóg terápiákkal szemben is rezisztensek lehetnek. Elkülönítésükben az eltérő klinikai manifesztáció mellett - a variáns típusnál a pancytopenia helyett inkább leukocy tosis figyelhető meg - a morfológiai és az immunfenotípusban jelentkező különbségek egyaránt segítségre lehetnek. vHCL-ben a sejtek blastos megjelenésúek, irreguláris magvúak prominens nukleolussal, továbbá hiányzik a CD25 és a CD123 expressziója, valamint a cHCL-ben szinte 100\%-ban jelen lévő BRAF V600E-mutáció is [13].

\section{A HCL diagnózisa}

\section{Morfológia}

Önálló entitásként való besorolása ellenére a HCL diagnosztikai kritériumai sokáig, egészen a 70-es évekig nem

1. táblázat. A HCL klasszikus és variáns típusának összehasonlítása

\begin{tabular}{lll}
\hline & \multicolumn{1}{c}{ Klasszikus HCL } & \multicolumn{1}{c}{ Variáns HCL } \\
\hline Immunfenotípus & CD11c, CD25, CD103, CD123, annexin A1 & CD25 és annexin A1 hiánya \\
\hline Molekuláris genetika & $\begin{array}{l}B R A F \text { V600E } \\
\text { mutált } I G H V 4-34\end{array}$ & $\begin{array}{l}\text { BRAF V600E hiánya } \\
\text { nem mutált } I G H V 4-34(40 \%) \\
M A P 2 K 1 \text {-mutáció }\end{array}$ \\
\hline Klinikai manifesztáció & pancytopenia & leukocytosis \\
\hline Terápia - kezdeti & $\begin{array}{l}\text { purin nukleotid analógok (cladribine, pentostatin) } \\
\text { interferon-alfa } \\
\text { rituximabkiegészítéssel }\end{array}$ & $\begin{array}{l}\text { rosszabb válasz a purin nukleozid analógokra, } \\
\text { ezért rituximabbal kombinálva }\end{array}$ \\
\hline $\begin{array}{l}\text { Terápia - relabált/ } \\
\text { refrakter }\end{array}$ & $\begin{array}{l}\text { purin nukleozid analógok rituximabkiegészítéssel } \\
\text { vemurafenib } \\
\text { moxetumomab pasudotox }\end{array}$ & $\begin{array}{l}\text { klinikai vizsgálatok alatt: moxetumomab pasudo- } \\
\text { tox, ibrutinib, trametinib }\end{array}$ \\
\hline
\end{tabular}


voltak egységesek. Ekkor mint lymphoproliferativ betegséget karakterizálták először, PAS (perjódsav-Schiff-reakció) és TRAP- (tartarátrezisztens savanyú foszfatáz) festés segítségével, diagnosztikus kritériumként pedig a szőrös sejtek jelenlétét határozták meg a perifériás vérvagy csontvelőmintákban [14].

A villosus morfológiával rendelkező tumorsejtek sok esetben a sejtek összekapaszkodását eredményezhetik, kromatin állományuk általában homogén és nucleolus nem látható. A csontvelő infiltrációja kezdetben intersticiális, ami később diffúzzá válhat. A hajas sejtek „tükörtojást” idéző sejtalak képét ölthetik magukra, középen elhelyezkedő maggal, szélesebb, víztiszta citoplazmával (1. ábra). A kóros sejtek jellemzően a csontvelőt infiltrálják, aminek mértéke különböző fokú lehet. A lép érintettsége is igen gyakori, ahol a tumorsejtek a vörös pulpát infiltrálják, pseudosinusokat alkotva, mely a vörös pulpa normális véráramlásának megszakadásának a következménye [13].

\section{Fehérjealapú diagnosztikus markerek}

A morfológián túl sejtfelszíni markerek azonosításával megbízható fehérjealapú diagnosztikai módszerek állnak a rendelkezésünkre. A csontvelő- és perifériás vérmintákból áramlási cytometria segítségével azonosíthatók a hajas sejtekre jellemző immunológiai markerek. Az érési folyamatokat megkezdő, bizonyos mértékben differenciálódott B-sejtekre karakterisztikus CD19 és CD20 mellett detektálhatóak a CD11c, CD22, CD25 (interleukin-2 receptor), CD103 (az a $\beta$-integrin a alegysége), CD123 markerek. Ugyanakkor a CD5, CD21, CD23 és a CD79B markerek legtöbbször nincsenek jelen a HCL sejtek felszínén [13].

A jellegzetes immunfenotípus (CD11c, CD103, CD123, CD25 markerek expressziója, illetve annak mértéke) segíti a morfológiailag és klinikailag is hasonló entitásoktól (HCL-variáns típusa vagy splenicus marginális zóna Bsejtes limfóma - SMZL) való elkülönítését.

Immunhisztokémiai (IHC) módszerrel, specifikus antitestek alkalmazásával is kimutathatóak a már említett markerek, így a CD20 (1. ábra), CD123, CD11c, de további, az esetek túlnyomó részében jelen lévő markerek is, így a TRAP (tartarát-rezisztens savanyú foszfatáz), DBA-44, annexin A1 (ANXA1), cyclin D1, p-ERK1/2 (foszforilált-ERK) és a BRAF V600E-mutáció is. Ez utóbbi kimutatására használt BRAF V600E-specifikus monoklonális ellenanyagot hazánkban rutinszerüen alkalmazzuk a diagnosztika során (1. ábra $E$ ). Az eljárás elterjedését viszonylag gyors kivitelezhetősége, magas szenzitivitása és specificitása, valamint költséghatékony volta magyarázza [15].

A közel 100\%-os specificitása és szenzitivitása alkalmassá teszi a klasszikus és variáns HCL (vHCL), valamint a HCL-hez hasonló morfológiával és immunfenotípussal rendelkező SMZL elkülönítésére is $[15,16]$. Ugyan a BRAF V600E-mutáció az SMZL-ek kis százalékában is kimutatható, de a már említett markerekkel való együttes használata segíti a pontos diagnózisalkotást [17].

\section{BRAF-mutáció vizsgálata}

A $B R A F$ az egyik leggyakoribb mutációt hordozó, protein kinázt kódoló gén a daganatos megbetegedésekben. Melanomában, papillaris pajzsmirigy-carcinomában és colorectalis carcinomában egyaránt gyakori az előfordulása [18]. 2011 óta ismert, hogy a klasszikus hajas sejtes leukémia patogenezisében meghatározó szerepet játszik a BRAF fehérje V600E-mutációja, mely $90 \%$ felett van jelen a klasszikus HCL-ben (cHCL), azonban egyéb érett Bsejtes neoplazmákból hiányzik, ezáltal kiemelt szerepet tölt be a differenciáldiagnosztikában [19, 20].

A BRAF egy szerin/threonin kináz, mely szabályozó szerepet tölt be a MAPK növekedési útvonalban, ezáltal a sejtek túlélésében, proliferációjában és differenciálódásában. Génjében a kódoló régió 1799. helyén lévő timinjének adeninre történő szubsztitúciója, a fehérjében a 600. kodonban található valinnak glutaminsavra történő cseréjét eredményezi, mely a protein folyamatos autofoszforilációjához, állandó aktivitásához vezet. Ezáltal a MAPK-útvonal függetlenné válása az extracelluláris növekedési szignáloktól túlzott mértékü sejtproliferációt eredményezhet, melynek következtében nő a malignus folyamatok kialakulásának a kockázata [21]. Bár a $B R A F$-mutáció kimutatható a csontvelői őssejtekből és a progenitor B-sejtekből, máig nem tisztázott, hogy milyen további genetikai és/vagy epigenetikai változások szükségesek a $B R A F$-mutáción kívül a HCL kialakulásához [22].

A BRAF V600E-mutáció stabil jelenléte a HCL-ben a B-sejtes lymphoproliferatív betegségek között egyedinek minősül. Krónikus lymphoid leukémia és myeloma multiplex néhány esetétől eltekintve a $B R A F$-mutáció nem jellemző egyéb B-sejtes malignitásokra. Mivel a $B R A F$ mutáció egy stabil, klonális eltérés, amely a betegség relapszusakor is megjelenik, alkalmasnak tünik a mérhető minimális reziduális betegség (MRD) monitorozására nagy szenzitivitású molekuláris diagnosztikai eljárások alkalmazásával [23]. A mutáció detektálására napjainkban már többféle lehetőség is rendelkezésre áll. A korábban már említett IHC technikával szemben kvantitatív meghatározásra ad lehetőséget a pyroszekvenálás módszere [24]. Fontos azonban kiemelni, hogy ez az eljárás nem képes detektálni az 5\%-nál alacsonyabb allélfrekvenciával bíró mutációkat, ezért a diagnosztika fejlesztése során újabb molekuláris módszerek kerültek bevezetésre. Idetartoznak az allélspecifikus PCR (AS-PCR) és a droplet digitális PCR (ddPCR) technikák, melyek magas szenzitivitásuknak (akár 0,01\%) köszönhetően az 1\% alatti allélfrekvenciával jelen lévő mutációkat is képesek kimutatni, újabb perspektívát nyitva az MRD nyomon követésében (2. ábra) [25, 26]. Hazánkban jelenleg az IHC technika mellett a pyroszekvenálás áll rendelkezésre a $B R A F$-mu- 


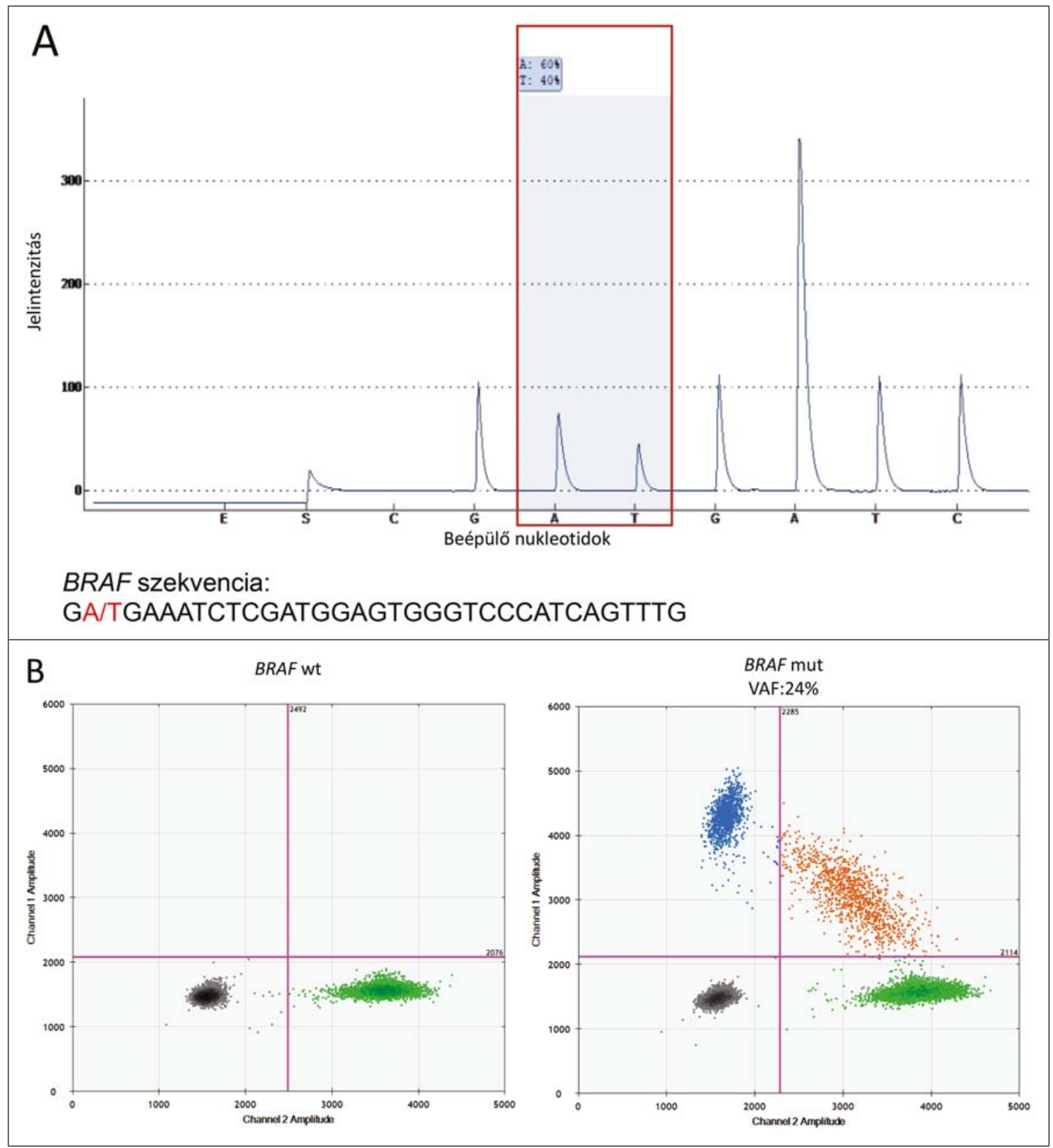

2. ábra. BRAF V600E-mutáció kimutatása pyroszekvenálással (A) és droplet digitális PCR (ddPCR) (B) módszerrel. A) A szekvenogramon az eredeti $B R A F$ nukleotid szekvenciához képest az 1799. pozícióban lévő timinnek adeninre történő kicserélődése látható. A jelintenzitásból leolvasható, milyen arányban vannak jelen a nukleotidok: adenin 60\%-ban, timin 40\%-ban volt jelen a mintában. B) ddPCR dotplot ábrájáról meghatározható a mutáns (kék) és a vad típusú (zöld) DNS mennyisége. Minden egyes pont egyedi reakciónak számít, mely ideális esetben egy cseppben egy DNS-molekulát tartalmaz. Amikor mutáns és vad típusú DNS-molekula is be kerül egy cseppbe, a dotploton narancssárga jelölést kap, az üres/DNS-mentes cseppek pedig szürke színnel jelennek meg. A mutáns és vad cseppek arányából kvantitatív módon kiszámíthatóvá válik a pontos variáns allélfrekvencia (VAF)

táció rutinszerű detektálására, továbbá egyes laboratóriumokban ddPCR-vizsgálat is elérhető.

\section{A HCL patogenezisében szerepet játszó további tényezők}

\section{Jelátviteli útvonalak szerepe}

A $B R A F$-mutáció a fehérje RAS-független aktiválódását, így a MEK-ERK jelátviteli útvonal fokozott múködését okozza. Mindez a sejtek túlélését, proliferációját, valamint anti-apoptotikus folyamatok indukálását eredményezi. Az útvonal aktiválódása ugyanis a PI3K-AKT jelútra is kihat, mely a lymphocytákban fontos szerepet tölt be a cyclin D1 expressziója révén - amely jellemzően fokozott a HCL sejtekben -, előidézve a sejtciklus G1-S fázisátmenetet (3. ábra) [27]. Szintén a PI3K-AKT útvonal aktiválódását idézheti elő az az autokrin szabályozási folyamat, mely során a hajas sejtek fibroblast növe- 


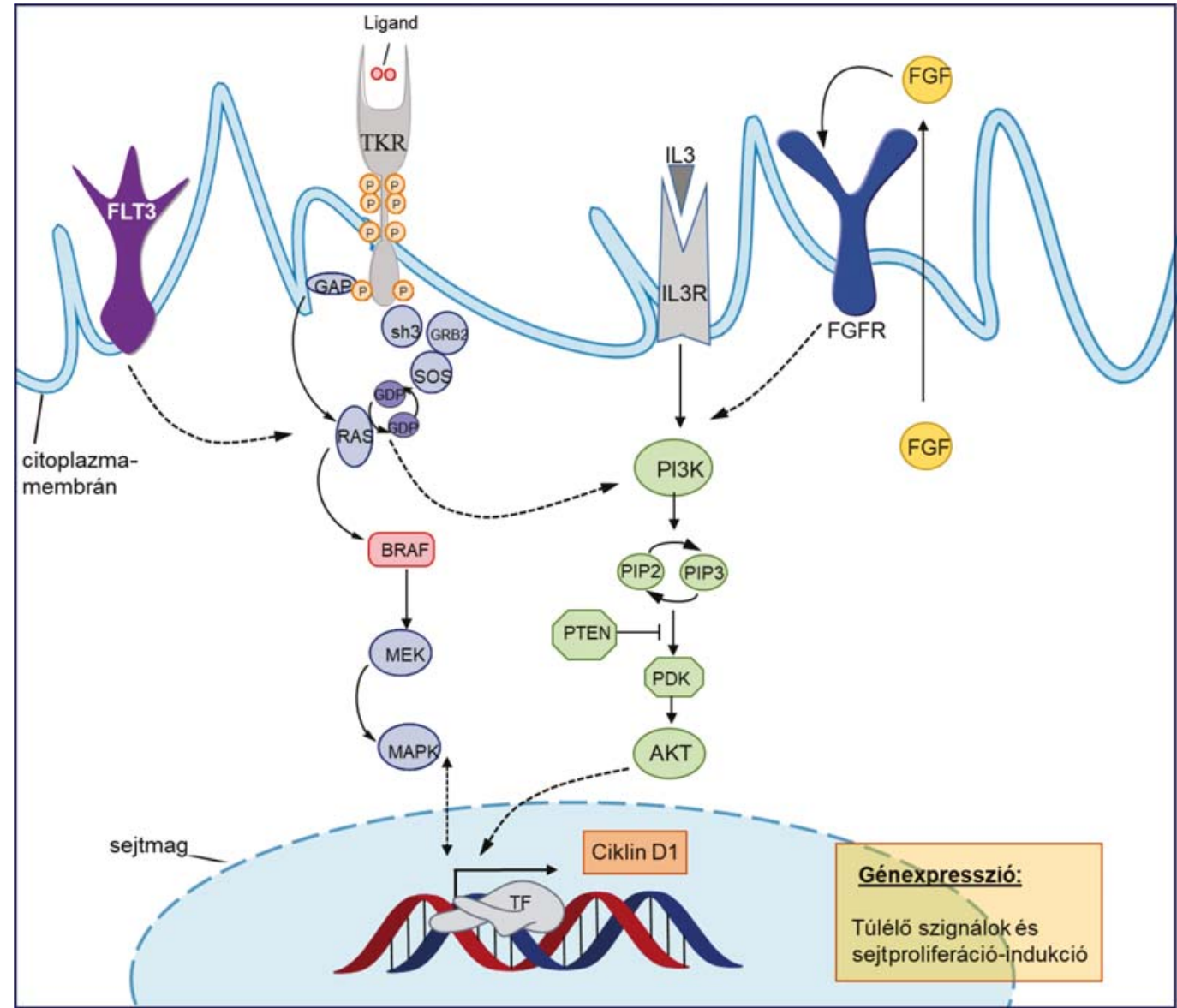

3. ábra. HCL tumorsejtek működését befolyásoló főbb jelátviteli útvonalak. A HCL-sejtek túlélésének és proliferációjának szabályozásában föként a RAS/BRAF/MAPK jelút és PI3K szignál vesz részt. A sejtet határoló nyúlványos szerkezetủ membránban jelen vannak azok a receptorok (FLT3, IL3R, FGFR), amelyek főként a két kiemelt útvonal aktiválódását fokozzák, más sejtek által (interleukinek) vagy autokrin módon (FGF) expresszált ligandok segítségével. (AKT - protein kináz B; BRAF - Raf murin sarcoma virális onkogén homológ B; FGF - fibroblastnövekedési faktor; FGFR - fibroblastnövekedési faktorreceptor; FLT3 - fms-szerü tirozin kináz receptor 3; GAP GTP-áz-aktiváló fehérjék; GRB2 - növekedési faktorreceptor kötőfehérje 2; GDP/GTP - guanozin difoszfát/trifoszfát; IL3R - interleukin 3 receptor; IL3 - interleukin 3; MAPK - mitogénaktivált protein kináz; MEK - mitogénaktiválta protein kináz; PI3K - foszfoinozit-3 kináz; PIP2/PIP3 - foszfoinozitid-4,5-biszfoszfát/foszfoinozitol-1,4-trifoszfát; PTEN - foszfatáz és tenzin homológ; RAS - patkány sarcomafehérje; SOS - guanin nukleotid kicserélő faktor; TKR - tirozin kináz receptor; TF - transzkripciós faktor)

kedési faktor (FGF) receptor 1 expressziója mellett FGFet, a receptor ligandját is termelik saját maguk számára, indukálva önmaguk növekedési szignálját [28, 29].

A morfológia kialakításában is kulcsszerepet játszik a BRAF-MEK jelátviteli útvonal aktivitása. A fentebb leírt morfológiaszabályzó gének expressziós mintázata mellett in vitro, primer hajas sejt sejttenyészetben igazolták a BRAF- és MEK-inhibitorok tumorsejtek morfológia átalakító hatását. A sejtek „szőrös” morfológiájukat elvesztették, kisebb és simább sejtformát vettek fel kezelés következtében [30]. A hajas sejtek felületnövelő citoplazmanyúlványaikon keresztül szoros kapcsolatban állnak az extracelluláris mátrix elemeivel. A csontvelő strómasejtjein található IL-3 és FLT3 ligandumok képesek a kifejezetten HCL sejteken expresszálódó IL-3 receptorhoz (CD123) és FLT3 receptorhoz kapcsolódni, segítve a tumorsejtek túlélését [7].

A tumorsejtek életben maradásán túl a szervezeten belüli lokalizációjukat is segíti a környezetükben lévő sej- tekkel kialakított kommunikáció. A HCL sejtek jellemzően vörösvérsejtekkel gazdagon ellátott területeket infiltrálnak, úgymint a lép vörös pulpája, csontvelő vagy a máj sinusoidjai. Ebben a „homing” folyamatban az endothelsejtek felszínén megtalálható vascularis sejtadhéziós molekula 1 (VCAM1) molekulák vannak segítségükre, valamint a sejtek által termelt mátrix metalloproteináz-inhibitorok (TIMP1,4), amelyek a tumorsejtek szöveti beágyazódását serkentik [7, 31, 32].

\section{Mikro-RNS-szabályozás}

A jelátviteli folyamatok szabályozásában a rövid, nem kódoló RNS-ek egyik legismertebb csoportja, a mikroRNS-ek (miRNS) is részt vesznek. Ezek a 19-22 nukleotid hosszúságú RNS molekulák a transzláció gátlásán keresztül több fontosabb központi fehérje aktivitását, s ezáltal a sejtek proliferációját, túlélését, anyagcsere-folyamatait befolyásolhatják. A HCL-es betegeket a miR-221, 


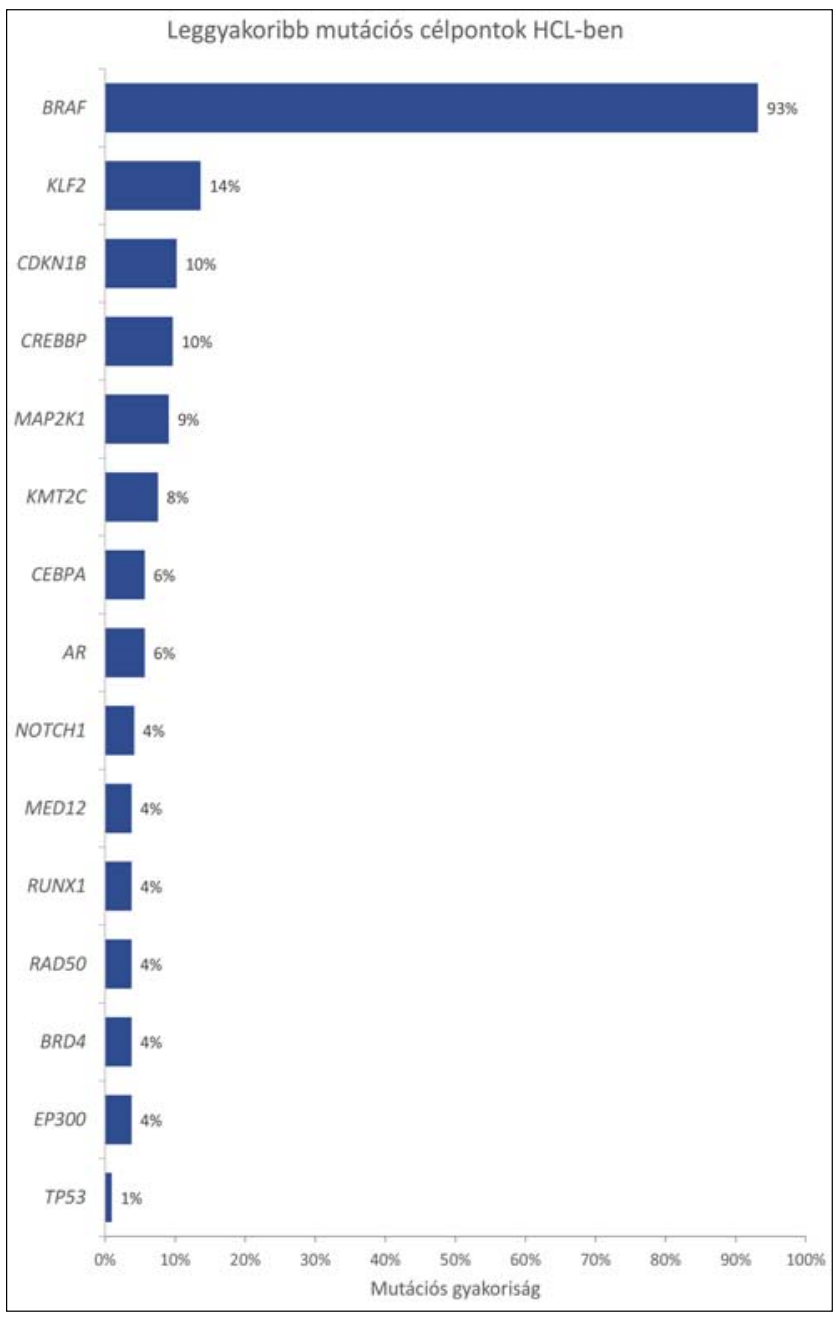

4. ábra. cHCL-ben leggyakrabban mutált gének prevalenciája. A diagram két kutatócsoport átfogó, új generációs szekvenálásalapú mutációs vizsgálatának átlagos mutációs gyakoriságát mutatja $[35,36]$

miR-222, miR-22, miR-24, miR-27 és Let-7b emelkedett expressziója jellemzi. Emellett a miR-221 és miR-222 expressziós szintje korrelációt mutat a $B R A F$-mutációval és a CDKN1B (p27) alacsony expressziójával, mely direkt célpontja lehet ezen miRNS-eknek [33, 34].

\section{További gének mutációi HCL-ben}

Kisebb HCL-es betegpopulációkon végzett NGS-vizsgálatok segítségével folyamatosan zajlik a HCL genetikai hátterének a feltérképezése. A $B R A F$-drivermutáción kívül patogén mutációkat írtak le számos más gén esetében is, többek között a $K M T 2 C$-, a $C D K N 1 B$-, a $K L F 2$ - vagy variáns HCL-ben a $M A P 2 K 1$-gén esetében (4. ábra) [35, 36].

A $C D K N 1 B$ egy tumorszuppresszort, a ciklindependens kinázinhibitor p27-et kódolja. A CDKN1B-mutációk 16\%-os gyakorisággal fordulnak elő cHCL-ben, az esetek $63 \%$-ban nonsense mutáció formájában. A HCL patogenezisében betöltött korai szerepére utal klonális jelen- léte, valamint az, hogy a sejtciklus szabályozása révén ellensúlyozhatná a $B R A F$ onkogén transzformációs potenciálját, ez azonban nyilvánvalóan hiányzik a daganatos sejtekből, amire a monoallélikus mutációi által okozott haploinszufficiencia ad magyarázatot. A fehérje expreszsziója minden HCL-es betegben jellemzően alacsony a mutáció státuszától függetlenül, így érdekes módon mindez nincs hatással a betegség kimenetelére és klinikai manifesztációjára [37-39].

A Krüppel-szerü faktor 2 (KLF2) egy transzkripciós faktor, mely szabályozza az érett B-sejt szubpopulációk homeosztázisát és differenciálódását. A KLF2-mutációk következtében létrejövő aminosavcserék az esetek döntő többségében funkcióvesztést okoznak, amelyek szerepe a HCL patogenezisében egyelőre ismeretlen [38].

A lizin N-metiltranszferáz 2C (KMT2C) mutációja a betegek 15\%-ában található meg. Alapvető feladata a 3-as hiszton 4-es lizin oldallánc (H3K4) metilációjának szabályozása. Pontos szerepe a HCL patogenezisében ez idáig nem ismert $[35,36,40]$.

Alacsony gyakorisággal, de további visszatérő mutációkat is detektáltak cHCL-ben, többek között a BRD4-, CEBPA-, CREBBP-, RUNX1-, EP300- és MED12-, továbbá a Notch szignalizációban szerepet játszó NOTCH1-, NOTCH2- géneknél. Ezenfelül NRTK1- és FLT1-géneket érintő mutációkat is leírtak, de ezek jelentősége jelenleg még nem ismert [35, 39].

A klasszikus HCL-en belül elkülöníthető egy alcsoport, amelyben IGHV4-34 génátrendeződés figyelhető meg az immunglobulin nehézláncgéneket illetően. Érdekes módon, a mutált konformációval rendelkező betegpopuláció klinikai jellemzőiben inkább hasonlít a variáns esetekre, az érintettek gyakran leukocytosissal jelentkeznek, agresszívabb betegséglefolyás jellemzi őket, és számos esetben refrakterek az önmagában alkalmazott cladribinekezelésre [41].

A vad típusú $B R A F$-génnel rendelkező HCL esetek nagy része variáns típusú, ezek közel felében írtak le valamilyen $M A P 2 K 1$-gént érintő mutációt, míg a $B R A F$-negatív klasszikus esetekben ez az arány még magasabb volt [42]. A $M A P 2 K 1$-szubsztitúciók attól függően, hogy a gén mely pontját érintik, a MAPK emelkedett foszforilációja révén az útvonal fokozott aktiválását okozhatják, valamint szerepet játszhatnak a MEK-inhibitorokkal szembeni érzékenység vagy akár rezisztencia kialakulásában is [36].

\section{A HCL klinikai jellemzői}

Hazánkban a Nemzeti Rákregiszter adatai alapján a hajas sejtes leukémia incidenciája 30-40 eset évente, a diagnózis időpontjában a betegek átlagéletkora 55 év körülire tehető. Nemek szerinti eloszlását tekintve a betegség négyszer gyakoribb a férfiak, mint a nők körében, emellett a kaukázusi rasszban a leggyakoribb az előfordulása. Környezeti rizikófaktoraiként tartják számon a mezőgazdasági tevékenység végzését, egyes kemikáliákkal (petró- 
2. táblázat. HCL-terápiás lehetőségek összehasonlítása

\begin{tabular}{|c|c|c|c|c|}
\hline & $\begin{array}{c}\text { Interferon-alfa } \\
{[54-57]}\end{array}$ & $\begin{array}{l}\text { Cladribine } \\
{[60-63,66]}\end{array}$ & $\begin{array}{c}\text { Vemurafenib } \\
{[75]}\end{array}$ & $\begin{array}{c}\text { Moxetumomab } \\
\text { pasudotox }[82,83]\end{array}$ \\
\hline & immunsejt-modulálás & purin nukleozid analóg & BRAF-inhibitor & $\begin{array}{l}\text { CD22-ellenes immuno- } \\
\text { toxin }\end{array}$ \\
\hline ORR (teljes válaszarány) & $69-89 \%$ & $100 \%$ & $96-100 \%$ & $75-86 \%$ \\
\hline CR (komplett remisszió) & $0-30 \%$ & $76-97 \%$ & $35-42 \%$ & $30-46 \%$ \\
\hline $\begin{array}{l}\text { PFS (medián progresz- } \\
\text { sziómentes túlélés) }\end{array}$ & 6-25 hónap & 15,5-42 hónap & 19-12 hónap & vizsgálat alatt \\
\hline Mellékhatások & $\begin{array}{l}\text { fáradtság, infekciók, } \\
\text { influenzaszerü tünetek, } \\
\text { átmeneti myeloszup- } \\
\text { presszió }\end{array}$ & láz, myeloszuppresszió & $\begin{array}{l}\text { láz, kiütések, fényérzé- } \\
\text { kenység, arthritis, } \\
\text { hyperbilirubinaemia, } \\
\text { bőr basalsejtes carci- } \\
\text { nomája }\end{array}$ & $\begin{array}{l}\text { ödéma, fáradtság, hány- } \\
\text { inger, csökkent lympho- } \\
\text { cytaszám, infekciók, } \\
\text { hemolitikus urémiás } \\
\text { szindróma, fokozott } \\
\text { kapillárisáteresztés- } \\
\text { szindróma }\end{array}$ \\
\hline
\end{tabular}

leum, dízel) és rovarirtó szerekkel való rendszeres érintkezést, valamint az ionizáló sugárzásnak való kitettséget [43, 44]. A betegek leggyakrabban a fáradtság és a gyakori ismétlődő fertőzések miatt keresik fel orvosaikat, amikor a fizikális vizsgálat során az esetek egy részében lépmegnagyobbodás tapasztalható [2]. Leginkább a csontvelő és a lép érintettsége jellemzi, a perifériális nyirokcsomómegnagyobbodás nem gyakori. A betegség előrehaladtával a csontvelői infiltráció következményeként a betegek mintegy $90 \%$-ában pancytopenia áll fenn, míg 10\%-ukban a vérkép leukémiás (leukocytosis mellett anémia és thrombocytopenia figyelhető meg), illetve a variáns típusnál ennek az ellenkezője, jelentős leukocytosis a jellemző [2, 45].

\section{A HCL kezelése}

A hajas sejtes leukémia hatásos szisztémás kezelését megelőzően a lépeltávolítás volt az alkalmazott terápiás eljárás, mely bár enyhítette a betegeknél jelentkező pancytopenia mértékét, de a legtöbb esetben csak időszakos javuláshoz vezetett [46, 47].

Az első jelentős javulást eredményező kezelést a természetes, majd a rekombináns interferon-alfa jelentette, mely az immunsejtek modulálása révén hatással van a kóros lymphoid sejtek növekedésére és differenciálódására. Amellett, hogy az immunrendszer serkentése révén fokozza a szervezet számára idegen antigének felismerését és a természetes ölősejtek cytotoxikus funkcióját, direkt módon is hatással van a hajas sejtekre. Módosítja egyes onkogének (pl.: c-fos) expresszióját és a citokinek (IL-6, TNFa) termelését, valamint specifikus fehérjék szintézisét indukálja [48-50]. Ezek összessége vezet a hajas sejtek differenciálódásához, továbbá a növekedési faktorokkal szembeni nagyobb ellenálló képességhez, így a proliferáció gátlásához [51, 52].
Egy angliai multicentrikus klinikai vizsgálatban (Cancer and Leukemia Group B - CALGB) rekombináns interferon-alfa-kezelés során a betegek jelentős részében (40/52) parciális remissziót (PR) értek el, a medián progressziómentes túlélés pedig meghosszabbodott több mint 8 hónappal (2. táblázat) [53-57]. Alkalmazásának korlátait a viszonylag gyakran jelentkező mellékhatások jelentik. Az esetek 75\%-ában fáradtság lép fel, az alkalmazás első hetében influenzaszerü tünetek, illetve átmenetileg myeloszuppresszió is kialakulhat, ezért napjainkban az újabb, hatásosabb terápiák már háttérbe szorították az interferon alkalmazását [53]. Biztonságosan adható azonban terhességben, továbbá olyan esetekben, ahol a purin analógok immunszuppresszív hatása elkerülendő [58, 59]. A rekombináns interferon-alfa készítmények egyike sem érhető el 2020 eleje óta, mivel kis forgalma miatt gyártásával világszerte leálltak a gyártók. Egyértelmű és kizárólagos interferon-alfa indikáció esetén ezért az OGYÉI (Országos Gyógyszerészeti és Élelmezés-egészségügyi Intézet) off-label engedélyének birtokában pegilált interferon-alfa készítmény adható. Ez heti egyszeri subcutan (sc.) injekciós kezelést jelent, kedvezőbb mellékhatás spektrummal.

A HCL kezelésében igazi áttörést a purin analógok (PA) jelentették, melyek 30 évvel az első alkalmazásukat követően is a hajas sejtes leukémia első vonalbeli kezelését képezik. Beépülve a DNS-be törést okoznak, leállítva ezzel a szintézist és a repairmechanizmusokat, ami a leukocyták apoptózisához vezet. A HCL-ben alkalmazott cladribine több klinikai tanulmány során is közel 100\%-os teljes válaszarányt eredményezett, 80-95\% komplett remisszió (CR) mellett (2. táblázat) [60-64]. A toxicitásbeli különbségekből adódóan, a kezdeti ajánlások szerinti 7 napos cladribinekezelést az 5 napos váltotta fel [65]. Az 5 napon át adott napi 2 órás infúzió, vagy az utóbbi évtizedben (2005-től) már sc. adott egyetlen kezelési ciklus fontos mellékhatása a kezelést követően hosszan fennálló szekunder immunhiányos állapot, amely a keze- 
lés utáni első két hónapban a legkifejezettebb [60, 66]. A kialakult neutropenia miatt granulocyta kolóniastimuláló faktor (G-CSF-) kezelés adható/adandó, sőt a pegilált G-CSF adásának az indikációja is megfogalmazható (bár első vonalbeli kezelésként ez hazánkban már sok éve nem finanszírozott). A G-CSF-kezelés naponkénti adása indokolt, ha a neutropeniás betegekben a kezelést követő - akár fokozódó - neutropenia kockázata meghaladja a 20\%-ot [67].

A másik PA a Streptomyces antibioticus baktérium által termelt anyag, a pentostatin hasonló kezelésbeli hatékonysággal rendelkezik, mint a cladribine. Az adenozin dezamináz (ADA) megkötését okozza, mely nélkülözhetetlen a lymphoid sejtek purin anyagcseréjéhez. Elhúzódó - 2 hetente 3-6 hónapig történő - adagolása miatt azonban háttérbe szorul, és mivel nem ismert keresztrezisztenciája a cladribine-nel, főként csak relapszust követően kerül sor az alkalmazására. Jelenleg hazánkban a HCL-es betegek kezelésében az egyetlen használatban lévő PA a cladribine [58, 68-70].

Egy további, a gyakorlatban előtérben álló lehetőség relapszus kialakulásakor a fent említett purin analógok, elsősorban a cladribine rituximabbal történő kombinálása. A kiméra anti-CD20 monoklonális antitest-B-sejtek elleni antiproliferatív és apoptózisindukáló hatását a többi B-sejtes malignitáshoz hasonlóan a HCL-ben is kifejti. Relabált betegeknél önmagában alkalmazva hatása sokszor nem kellően tartós, cladribine-nel kombinálva azonban a relabált és cladribine-nel szemben primer refrakteritással rendelkező betegek esetében nagymértékü, 80\%-os teljes válaszarány (ORR) volt megfigyelhető [71, 72]. Ha a relapszus a cladribinekezelés után két évvel vagy még később következik be, a cladribine ismételt alkalmazását követően 1-2 hónappal később rituximabkezelése javasolt, melynek során $4-8$ héten át hetente $1 \times 375 \mathrm{mg} / \mathrm{m}^{2}$ intravénás (iv.) rituximab adására kerül sor $[73,74]$.

A $B R A F$ V600E-mutációnak nemcsak a diagnózis felállításában van fontos szerepe, de egyben terápiás célpont is. $\mathrm{Az}$ eredetileg melanoma kezelésére kifejlesztett vemurafenib az azonos támadáspontnak köszönhetően bevethető a hajas sejtes leukémia kezelésében is. A $B R A F$ mutációja a klasszikus esetek közel 100\%-ában jelen van. Vemurafenib vagy más BRAF-gátló kezelés alkalmazása természetesen csak ezen esetekben jön szóba, egy vagy

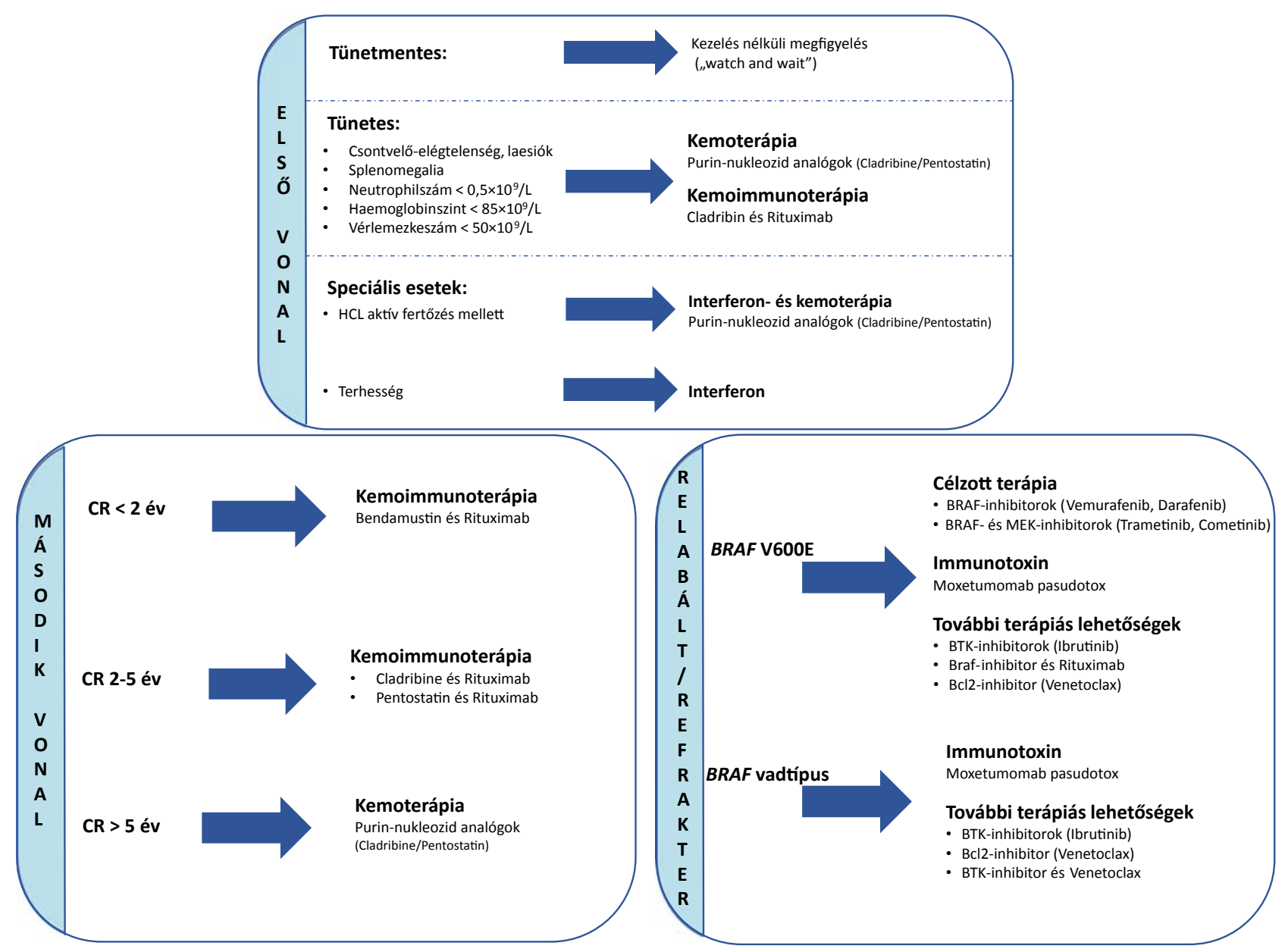

5. ábra. cHCL-es betegek terápiás lehetőségei. Maitre és munkatársai az amerikai hematológiai újság (AJH) összefoglalójában leírt legfrissebb terápiás ajánlásai, melyet az összes eddigi HCL-kezelési protokollokat összevető metaanalízisen alapuló algoritmus segítségével állítottak össze $[87,88]$ 
3. táblázat. Hamarosan induló vagy jelenleg is folyamatban lévő klinikai vizsgálatok HCL-ben

\begin{tabular}{lllc}
\hline $\begin{array}{l}\text { Klinikai vizsgálat } \\
\text { azonosítója }\end{array}$ & \multicolumn{1}{c}{ Alkalmazott szer } & \multicolumn{1}{c}{ Vizsgált betegcsoport } & $\begin{array}{l}\text { Vizsgálat } \\
\text { fázisa }\end{array}$ \\
\hline NCT01711632 & vemurafenib & relabált/refrakter HCL & fázis 2 \\
NCT00321555 & Anti-Tac(Fv)-PE38 (LMB-2) immunotoxin & CD25+ HCL & fázis 2 \\
NCT02131753 & sc. cladribine injekció & HCL & fázis 2, 3 \\
NCT04322383 & binimetinib & BRAF wt relabált/refrakter HCL és HCLv & fázis 2 \\
NCT03805932 & moxetumomab pasudotox + rituximab & refrakter HCL és HCLv & fázis 1 \\
NCT00923013 & iv. cladribine + rituximab & HCL és HCLv & fázis 2 \\
NCT00412594 & iv. cladribine + rituximab & relabált HCL & fázis 2 \\
NCT01059786 & rituximab + pentostatin/bendamustine & relabált/refrakter HCL & fázis 2 \\
NCT01841723 & ibrutinib & relabált HCL & fázis 2 \\
NCT03410875 & vemurafenib + obinutuzumab & kezeletlen HCL & fázis 2 \\
NCT04324112 & binimetinib + encorafenib & BRAF mt relabált/refrakter HCL & fázis 2 \\
\hline
\end{tabular}

több előzetes kezelési vonal sikertelensége vagy relapszus esetén. Ugyanakkor a vemurafenibbel kezelt betegek, még ha a kezelés során komplett remisszióba is kerülnek, gyakran relabálnak (5. ábra) [75]. Fontos kiemelni, hogy HCL-ben a vemurafenibkezelési protokoll különbözik a melanoma malignumban alkalmazottól. Míg a melanoma malignumban napi $2 \times 960 \mathrm{mg}$ tartós szedése a szokásos adag, addig HCL-ben ennél jóval kisebb, $2 \times 240$ mg vagy $2 \times 480 \mathrm{mg}$ vemurafenib két hónapon át történő szedése is már eredményes lehet [76]. A BRAF-gátlók - átmenetileg legalábbis - önmagukban is hatásosak a $B R A F$-mutációt hordozó klasszikus HCL kezelésében, komplett vagy parciális választ eredményezve.

A BRAF gátlószer-kezelés mellékhatásaként láz, kiütések, fényérzékenység, arthritis, valamint hyperbilirubinaemia léphet fel, melyek közül a fényérzékenység már a csökkentett dózisú alkalmazás esetén is kialakul. Fontos továbbá a betegek vemurafenibkezelés megkezdésekor történő bőrgyógyászati vizsgálata és további ellenőrzése, ugyanis melanoma malignum miatt vemurafenibbel kezelt betegekben több esetben leírták a bőr basalsejtes carcinomájának kialakulását [77, 78].

A vemurafenib HCL-ben történő alkalmazásának legfontosabb indikációja jelenleg az infekcióban, elsősorban lázas neutropeniában szenvedő HCL-es betegek kezelése. A COVID-19-járvány idején zajló COVID-infekció esetén pedig ez az a kezelési mód, amely nem okoz neutropeniát, tehát tulajdonképpen készenléti szernek tekinthető ilyen esetekben [79]. Mivel a vemurafenib HCL-ben nem rendelkezik törzskönyvvel, ezért megelőzően minden esetben az OGYÉI off-label engedélye szükséges az alkalmazásához. Másik fontos indikációs területe továbbá a relabálórefrakter hajas sejtes leukémia. Mivel azonban ez a kezelés általában nem eredményez tartós remissziót, ezért olasz kutatók a vemurafenibet rituximabbal kombinációban is alkalmazták ilyen esetekben. Ez a kezelési protokoll rövid időtartamú, biztonságos és nem myelotoxikus [80]. A COVID-19-pandémia idején azonban a rituximab im- munszuppresszív hatása miatt csak kivételesen, különösen indokolt esetben adható [79].

Néhány éve megjelent újabb lehetőség a moxetumomab pasudotox (MPT), mely a CD22-ellenes antitest $\mathrm{F}_{\mathrm{v}}$-régiójának és a Pseudomonas exotoxin A-nak (PE38) a fúziója. A cHCL-ben és vHCL-ben jelen lévő hajas sejtek egyaránt nagy mennyiségben expresszálnak CD22-t. Az MPT a CD22 molekulához kötődve endocitózissal bejut a sejtbe, és proteinszintézis gátláshoz, valamint apoptózishoz vezet [81]. Az MPT-t az FDA (az USA Élelmiszer-biztonsági és Gyógyszerészeti Hivatala) 2018-ban törzskönyvezte felnőtt, korábban legalább 2 szisztémás és legalább 1 purin nukleozid analógot tartalmazó kezelésen átesett HCL-ben szenvedő betegek intravénás kezelésére. A Lumoxiti (MPT) a betegek mintegy 25\%-ában jelenthet majd új kezelési modalitást, és hozzájárulhat a betegség célzott kezeléséhez. Klinikai vizsgálatok alapján korábban már több kezelési vonalon is átesett páciensek esetében 75\%-os teljes válaszarány volt megfigyelhető az MPT alkalmazásával, mely az esetek felében hosszú távú komplett remiszsziót eredményezett. Immunotoxinként különös odafigyelést igényelnek a jelentkező mellékhatások, az enyhébb tünetek mellett lymphocytaszám-csökkenés, fertőzések, hemolitikus urémiás szindróma és fokozott kapillárisáteresztés-szindróma felléptét írták le, melyek azonban az esetek többségében szupportív kezeléssel reverzibilisnek bizonyultak (2. táblázat) [82-84].

A nem kemoterápiás lehetőségek közé tartozik még a MAPK-jelátviteli útvonal egy másik elemének, a MEKnek a célzott gátlása trametinibbel, valamint a krónikus lymphocytás leukémiában is alkalmazott, Bruton tirozin kináz gátlására szolgáló ibrutinib. A trametinib feltehetően hatásos a $M A P 2 K 1$-mutációval rendelkező vHCL esetekben, míg az ibrutinib a korábban már többször is relabált betegek esetében bár csak 46\%-os teljes válaszarány mutatott, szintén jelentős szerepet játszhat a későbbiekben a nehezen kezelhető variáns HCL kezelésében [85]. 
Napjainkban is folyamatosan zajlanak a korábban már leírt kezelési lehetőségek további optimalizálásához szükséges klinikai vizsgálatok. Ilyen például a subcutan cladribine-injekcióé, valamint különböző szerek kombinálásával próbálnak hatásosabb válaszreakciót kiváltani a relabált, valamint az eleve nehezebben kezelhető variáns esetekben. Új szerek kezelésbe való bevonására is történnek kísérletek, mint például a MEK-inhibitor binimetinib vagy éppen az LMB-2 CD25-ellenes rekombináns immunotoxin alkalmazása a HCL-es esetekben $[75,86]$ (3. táblázat).

\section{Összefoglalás}

A hajas sejtes leukémia molekuláris és sejtszintű müködésének vizsgálatai az utóbbi években sokat lendítettek a betegség mélyebb megértésén és az újabb terápiás alternatívák bevezetésén. A legújabb WHO-klasszifikáció során nagy hangsúlyt kaptak a genetikai hátteret és a tumorsejtek eredetét érintő egyre alaposabb ismeretek. A $B R A F$-mutációs státusz meghatározása és az útvonal hiperaktiválódásának ismerete lehetőséget adott a célzott kezelés bevezetésére, ezenfelül a hozzá kapcsolódó egyéb szabályozási folyamatok feltérképezése további alternatívákat nyújt a terápiás paletta színesítéséhez. Az eddig ismert, differenciáldiagnosztikában vizsgált felszíni markereken (CD11c, CD25, CD103, CD123) túl, az új, érzékenyebb és specifikusabb molekuláris módszerekkel mint a ddPCR vagy NGS technikák - még pontosabbá vált a HCL és rokonbetegségeinek elkülönítése, valamint lehetőség nyílt a betegek monitorozására és relapszusainak korai diagnosztizálására is.

A hajas sejtes leukémia terápiájában a nemzetközi irányelvek a purin nukleozid analóg kezelést javasolják első vonalban, mely régiónkban a sc. cladribinekezelés egyetlen ciklusát jelenti. Aktuálisan infekcióban szenvedő betegeknek ez azonban nem adható, esetükben, illetve a COVID-19-pandémia idején első vonalban a BRAF-gátló vemurafenib (off-label engedéllyel), továbbá az interferon-alfa jön szóba. A HCL kezelésének hazai irányelvében is az interferon-alfa szerepel a kezelési algoritmus egyik lehetséges első lépéseként annak immunológiai szempontból ismert előnyei miatt. Szerepe van továbbá a rituximabnak, elsősorban kis tumortömeggel járó relapszus esetén, valamint abban az esetben, ha a kemoterápia ellenjavallt. A COVID-19-járvány során ez az ajánlás azonban különösen megfontolandó, hiszen a rituximab immunszuppresszív hatású. A relabáló-refrakter HCL kezelésénél a további lehetőségek alkalmazása során szerepet játszik a beteg életkora, kísérőbetegségei, az előző kezelés óta eltelt idő, és természetesen az is, hogy a betegség $B R A F$-mutáció-pozitív-e. A hajas sejtes leukémiás betegek, különösen a relabáló-refrakter esetek optimális kezelése nagymértékben egyénre szabott.
Nyilatkozat: A kézirat korábban más folyóiratban nem jelent meg, és máshova beküldésre nem került. A levelező szerző elolvasta a Hematológia és Transzfuziológia szerzői útmutatóját.

Érdekeltségek: A szerzőknek a közleményhez kapcsolódó érdekeltségeik nincsenek.

Anyagi támogatás: A közlemény megírását Nemzeti Kutatási, Fejlesztési és Innovációs Hivatal (NKFIH) KH17126718, NVKP_16-1-2016-0004, FK20_134253 and K_16 \#119950 számú pályázatai, a Magyar Tudományos Akadémia LP-95021 számú Lendület és a Bolyai János Kutatási Ösztöndíj programja (BO/00320/18/5), valamint az Innovációs és Technológiai Minisztérium ÚNKP-19-4-SE-77, ÚNKP-19-2-I-SE-47 and ÚNKP-20-5-SE-22 kódszámú Új Nemzeti Kiválósági Programjai és a Semmelweis Egyetem Kiegészítő Kutatási Kiválósági Ösztöndíja az EFOP-3.6.3VEKOP-16-2017-00009 számú pályázata támogatta.

Szerzői munkamegosztás: B.Cs.: az összefoglaló szerkezeti, strukturális felépítésének megtervezése, molekuláris diagnosztikai eszközök és módszerekről szóló részek áttekintése és korrektúrája. D.J.: Klinikai kezelési protokollok és terápiás lehetőségek átolvasása, kijavítása és kibővítése szakmai tapasztalatai és irodalmi ismeretei alapján. N.N.: A kézirattal kapcsolatos munkák koordinálása. T.B.: Patológiai és diagnosztikai vizsgálatok és módszerek szakmai áttekintése, kiegészítése. Szövettani fotók elkészítése. I.G., N.N.: Az összefoglaló megírása, a hozzátartozó ábrák, táblázatok elkészítése. A cikk végleges változatát valamennyi szerző elolvasta és jóváhagyta.

\section{Irodalom}

[1] Teras LR, DeSantis CE, Cerhan JR, et al. 2016 US lymphoid malignancy statistics by World Health Organization subtypes. CA Cancer J Clin. 2016; 66: 443-459.

[2] Bouroncle BA, Wiseman BK, Doan CA. Leukemic reticuloendotheliosis. Blood 1958; 13: 609-630.

[3] Burns GF, Cawley JC. A re-examination of the alleged monocytic features of hairy-cell leukaemia. Scand J Haematol. 1979; 22: 386-396.

[4] Saxon A, Stevens RH, Golde DW. T-lymphocyte variant of hairycell leukemia. Ann Intern Med. 1978; 88: 323-326.

[5] Schrek R, Donnelly WJ. "Hairy" cells in blood in lymphoreticular neoplastic disease and "flagellated" cells of normal lymph nodes. Blood 1966; 27: 199-211.

[6] Kontrogianni-Konstantopoulos A, Frye CS, Benz EJ, Jr., et al. The prototypical $4.1 \mathrm{R}-10-\mathrm{kDa}$ domain and the $4.1 \mathrm{~g}-10-\mathrm{kDa}$ paralog mediate fodrin-actin complex formation. J Biol Chem. 2001; 276: 20679-20687.

[7] Basso K, Liso A, Tiacci E, et al. Gene expression profiling of hairy cell leukemia reveals a phenotype related to memory B cells with altered expression of chemokine and adhesion receptors. J Exp Med. 2004; 199: 59-68.

[8] Forconi F, Sahota SS, Raspadori D, et al.: Hairy cell leukemia: at the crossroad of somatic mutation and isotype switch. Blood 2004; 104: 3312-3317.

[9] Seifert M, Kuppers R. Human memory B cells. Leukemia 2016; 30: 2283-2292.

[10] Anderson KC, Boyd AW, Fisher DC, et al. Hairy cell leukemia: a tumor of pre-plasma cells. Blood 1985; 65: 620-629. 
[11] Thorselius M, Walsh SH, Thunberg U, et al. Heterogeneous somatic hypermutation status confounds the cell of origin in hairy cell leukemia. Leuk Res. 2005; 29: 153-158.

[12] Forconi F, Raspadori D, Lenoci M, et al.: Absence of surface CD27 distinguishes hairy cell leukemia from other leukemic B-cell malignancies. Haematologica 2005; 90: 266-268.

[13] Shao H, Calvo KR, Gronborg M, et al. Distinguishing hairy cell leukemia variant from hairy cell leukemia: development and validation of diagnostic criteria. Leuk Res. 2013; 37: 401-409.

[14] Catovsky D, Pettit JE, Galton DA, et al. Leukaemic reticuloen dotheliosis ('Hairy' cell leukaemia): a distinct clinico-pathological entity. Br J Haematol. 1974; 26: 9-27.

[15] Wang XJ, Kim A, Li S. Immunohistochemical analysis using a BRAF V600E mutation specific antibody is highly sensitive and specific for the diagnosis of hairy cell leukemia. Int J Clin Exp Pathol. 2014; 7: 4323-4328.

[16] Andrulis M, Penzel R, Weichert W, et al. Application of a BRAF V600E mutation-specific antibody for the diagnosis of hairy cell leukemia. Am J Surg Pathol. 2012; 36: 1796-1800.

[17] Turakhia S, Lanigan C, Hamadeh F, et al. Immunohistochemistry for BRAF V600E in the differential diagnosis of hairy cell leukemia vs other splenic B-cell lymphomas. Am J Clin Pathol. 2015; 144: 87-93.

[18] Davies H, Bignell GR, Cox C, et al.: Mutations of the BRAF gene in human cancer. Nature 2002; 417: 949-954.

[19] Arcaini L, Zibellini S, Boveri E, et al. The BRAF V600E mutation in hairy cell leukemia and other mature B-cell neoplasms. Blood 2012; 119: 188-191.

[20] Tiacci E, Trifonov V, Schiavoni G, et al. BRAF mutations in hairycell leukemia. N Engl J Med. 2011; 364: 2305-2315.

[21] Ahmadzadeh A, Shahrabi S, Jaseb K, et al. BRAF mutation in hairy cell leukemia. Oncol Rev. 2014; 8: 253.

[22] Chung SS, Kim E, Park JH, et al. Hematopoietic stem cell origin of BRAFV600E mutations in hairy cell leukemia. Sci Transl Med. 2014; 6: 238ra271.

[23] Jebaraj BM, Kienle D, Buhler A, et al. BRAF mutations in chronic lymphocytic leukemia. Leuk Lymphoma 2013; 54: 1177-1182.

[24] Verma S, Greaves WO, Ravandi F, et al. Rapid detection and quantitation of BRAF mutations in hairy cell leukemia using a sensitive pyrosequencing assay. Am J Clin Pathol. 2012; 138: $153-$ 156.

[25] Guerrini F, Paolicchi M, Ghio F, et al. The droplet digital PCR: A new valid molecular approach for the assessment of B-RAF V600E mutation in hairy cell leukemia. Front Pharmacol. 2016; 7 : 363.

[26] Tiacci E, Schiavoni G, Forconi F, et al. Simple genetic diagnosis of hairy cell leukemia by sensitive detection of the BRAF-V600E mutation. Blood 2012; 119: 192-195.

[27] Brennan P, Babbage JW, Burgering BM, et al. Phosphatidylinositol 3-kinase couples the interleukin-2 receptor to the cell cycle regulator E2F. Immunity 1997; 7: 679-689.

[28] Gruber G, Schwarzmeier JD, Shehata M, et al. Basic fibroblast growth factor is expressed by CD19/CD11c-positive cells in hairy cell leukemia. Blood 1999; 94: 1077-1085.

[29] Aziz KA, Till KJ, Chen H, et al. The role of autocrine FGF-2 in the distinctive bone marrow fibrosis of hairy-cell leukemia (HCL). Blood 2003; 102: 1051-1056.

[30] Pettirossi V, Santi A, Imperi E, et al. BRAF inhibitors reverse the unique molecular signature and phenotype of hairy cell leukemia and exert potent antileukemic activity. Blood 2015; 125: $1207-$ 1216.

[31] Burthem J, Baker PK, Hunt JA, et al. Hairy cell interactions with extracellular matrix: expression of specific integrin receptors and their role in the cell's response to specific adhesive proteins. Blood 1994; 84: 873-882.

[32] Vincent AM, Burthem J, Brew R, et al. Endothelial interactions of hairy cells: the importance of alpha 4 beta 1 in the unusual tissue distribution of the disorder. Blood 1996; 88: 3945-3952.
[33] le Sage C, Nagel R, Egan DA, et al. Regulation of the p27(Kip1) tumor suppressor by miR-221 and miR-222 promotes cancer cell proliferation. EMBO J. 2007; 26: 3699-3708.

[34] Kitagawa Y, Brahmachary M, Tiacci E, et al. A microRNA signature specific for hairy cell leukemia and associated with modulation of the MAPK-JNK pathways. Leukemia 2012; 26: 2564-2567.

[35] Durham BH, Getta B, Dietrich S, et al. Genomic analysis of hairy cell leukemia identifies novel recurrent genetic alterations. Blood 2017; 130: 1644-1648.

[36] Maitre E, Bertrand P, Maingonnat C, et al. New generation sequencing of targeted genes in the classical and the variant form of hairy cell leukemia highlights mutations in epigenetic regulation genes. Oncotarget 2018; 9: 28866-28876.

[37] Chu IM, Hengst L, Slingerland JM. The Cdk inhibitor p27 in human cancer: prognostic potential and relevance to anticancer therapy. Nat Rev Cancer 2008; 8: 253-267.

[38] Tiacci E, Pettirossi V, Schiavoni G, et al. Genomics of hairy cell leukemia. J Clin Oncol. 2017; 35: 1002-1010.

[39] Dietrich S, Hullein J, Lee SC, et al. Recurrent CDKN1B (p27) mutations in hairy cell leukemia. Blood 2015; 126: 1005-1008.

[40] Vallianatos CN, Iwase S. Disrupted intricacy of histone H3K4 methylation in neurodevelopmental disorders. Epigenomics 2015; 7: 503-519.

[41] Arons E, Suntum T, Stetler-Stevenson M, et al. VH4-34+ hairy cell leukemia, a new variant with poor prognosis despite standard therapy. Blood 2009; 114: 4687-4695.

[42] Waterfall JJ, Arons E, Walker RL, et al. High prevalence of MAP2K1 mutations in variant and IGHV4-34-expressing hairycell leukemias. Nat Genet. 2014; 46: 8-10.

[43] Bernstein L, Newton P, Ross RK. Epidemiology of hairy cell leukemia in Los Angeles County. Cancer Res 1990; 50: 3605-3609.

[44] Tadmor T, Polliack A. Epidemiology and environmental risk in hairy cell leukemia. Best Pract Res Clin Haematol. 2015; 28: 175179.

[45] Frassoldati A, Lamparelli T, Federico M, et al. Hairy cell leukemia: a clinical review based on 725 cases of the Italian Cooperative Group (ICGHCL). Italian Cooperative Group for Hairy Cell Leukemia. Leuk Lymphoma 1994; 13: 307-316.

[46] Jansen J, Hermans J. Splenectomy in hairy cell leukemia: a retrospective multicenter analysis. Cancer 1981; 47: 2066-2076.

[47] Van Norman AS, Nagorney DM, Martin JK, et al. Splenectomy for hairy cell leukemia. A clinical review of 63 patients. Cancer 1986; 57: 644-648.

[48] Paganelli KA, Evans SS, Han T, et al.: B cell growth factor-induced proliferation of hairy cell lymphocytes and inhibition by type I interferon in vitro. Blood 1986; 67: 937-942.

[49] Lehn P, Sigaux F, Grausz D, et al. c-myc and c-fos expression during interferon-alpha therapy for hairy cell leukemia. Blood 1986; 68: 967-970.

[50] Heslop HE, Bianchi AC, Cordingley FT, et al. Effects of interferon alpha on autocrine growth factor loops in B lymphoproliferative disorders. J Exp Med. 1990; 172: 1729-1734.

[51] Sigaux F, Castaigne S, Lehn P, et al. Alpha-interferon in hairy cell leukaemia: direct effects on hairy cells or indirect cytotoxicity? Int J Cancer Suppl. 1987; 1: 2-8.

[52] Vedantham S, Gamliel H, Golomb HM. Mechanism of interferon action in hairy cell leukemia: a model of effective cancer biotherapy. Cancer Res. 1992; 52: 1056-1066.

[53] Rai KR, Davey F, Peterson B, et al. Recombinant alpha-2b-interferon in therapy of previously untreated hairy cell leukemia: longterm follow-up results of study by Cancer and Leukemia Group B. Leukemia 1995; 9: 1116-1120.

[54] Quesada JR, Reuben J, Manning JT, et al. Alpha interferon for induction of remission in hairy-cell leukemia. N Engl J Med. 1984; 310: $15-18$.

[55] Berman E, Heller G, Kempin S, et al. Incidence of response and long-term follow-up in patients with hairy cell leukemia treated with recombinant interferon alfa-2a. Blood 1990; 75: 839-845. 
[56] Ratain MJ, Golomb HM, Vardiman JW, et al. Relapse after interferon alfa-2b therapy for hairy-cell leukemia: analysis of prognostic variables. J Clin Oncol. 1988; 6: 1714-1721.

[57] Golomb HM, Ratain MJ, Fefer A, et al. Randomized study of the duration of treatment with interferon alfa- $2 \mathrm{~B}$ in patients with hairy cell leukemia. J Natl Cancer Inst. 1988; 80: 369-373.

[58] Grever MR, Abdel-Wahab O, Andritsos LA, et al. Consensus guidelines for the diagnosis and management of patients with classic hairy cell leukemia. Blood 2017; 129: 553-560.

[59] Yazdani Brojeni P, Matok I, Garcia Bournissen F, et al. A systematic review of the fetal safety of interferon alpha. Reprod Toxicol. 2012; 33: 265-268.

[60] Goodman GR, Burian C, Koziol JA, et al. Extended follow-up of patients with hairy cell leukemia after treatment with cladribine. J Clin Oncol. 2003; 21: 891-896.

[61] Tallman MS, Hakimian D, Variakojis D, et al. A single cycle of 2-chlorodeoxyadenosine results in complete remission in the majority of patients with hairy cell leukemia. Blood 1992; 80: 22032209.

[62] Hoffman MA, Janson D, Rose E, et al. Treatment of hairy-cell leukemia with cladribine: response, toxicity, and long-term follow-up. J Clin Oncol. 1997; 15: 1138-1142.

[63] Khorshid O, Namour AE, El-Gammal MM, et al. Efficacy and Safety of Cladribine: Subcutaneous versus Intravenous Administration in Hairy Cell Leukemia Patients. Mediterr J Hematol Infect Dis. 2015; 7: e2015058.

[64] Lopez Rubio M, Da Silva C, Loscertales J, et al. Hairy cell leukemia treated initially with purine analogs: a retrospective study of 107 patients from the Spanish Cooperative Group on Chronic Lymphocytic Leukemia (GELLC). Leuk Lymphoma 2014; 55: $1007-1012$.

[65] Forconi FEC, Zaja F, Intermesoli T, et al. Analysis of toxicity and efficacy of subcutaneous cladribine at reduced or standard doses (five versus seven consecutive days) in patients with hairy cell leukemia (HCL) in the ICGHCL2004 protocol by the Italian Cooperative Group on HCL. Blood 2010; 116: 701.

[66] Piro LD, Carrera CJ, Carson DA, et al. Lasting remissions in hairy-cell leukemia induced by a single infusion of 2-chlorodeoxyadenosine. N Engl J Med. 1990; 322: 1117-1121.

[67] Aapro MS, Bohlius J, Cameron DA, et al. 2010 update of EORTC guidelines for the use of granulocyte-colony stimulating factor to reduce the incidence of chemotherapy-induced febrile neutropenia in adult patients with lymphoproliferative disorders and solid tumours. Eur J Cancer 2011; 47: 8-32.

[68] Spiers AS. Deoxycoformycin (pentostatin): clinical pharmacology, role in the chemotherapy of cancer, and use in other diseases. Haematologia (Budap) 1996; 27: 55-84.

[69] Dearden CE, Matutes E, Hilditch BL, et al. Long-term follow-up of patients with hairy cell leukaemia after treatment with pentostatin or cladribine. Br J Haematol. 1999; 106: 515-519.

[70] Else M, Dearden CE, Matutes E, et al. Long-term follow-up of 233 patients with hairy cell leukaemia, treated initially with pentostatin or cladribine, at a median of 16 years from diagnosis. $\mathrm{Br}$ J Haematol. 2009; 145: 733-740.

[71] Sadeghi N, Li HC. MRD-negative complete remission in relapsed refractory hairy cell leukemia with bendamustine and obinutuzumab. Ann Hematol. 2018; 97: 723-724.
[72] Thomas DA, O'Brien S, Bueso-Ramos C, et al. Rituximab in relapsed or refractory hairy cell leukemia. Blood 2003; 102: 39063911.

[73] Leclerc M, Suarez F, Noel MP, et al.: Rituximab therapy for hairy cell leukemia: a retrospective study of 41 cases. Ann Hematol. 2015; 94: 89-95.

[74] Chihara D, Kantarjian H, O'Brien S, et al. Long-term durable remission by cladribine followed by rituximab in patients with hairy cell leukaemia: update of a phase II trial. Br J Haematol. 2016; 174: 760-766.

[75] Tiacci E, Park JH, De Carolis L, et al. Targeting mutant BRAF in relapsed or refractory hairy-cell leukemia. N Engl J Med. 2015; 373: 1733-1747.

[76] Dietrich S, Pircher A, Endris V, et al. BRAF inhibition in hairy cell leukemia with low-dose vemurafenib. Blood 2016; 127: 28472855.

[77] Falini B, Tiacci E. New treatment options in hairy cell leukemia with focus on BRAF inhibitors. Hematol Oncol. 2019; 37 Suppl 1: 30-37.

[78] Sari E, Nagy ZG, Baghy K, et al. Treatment of refractory hairy cell leukemia with a BRAF-inhibitor: lessons to be learnt. Pathol Oncol Res. 2014; 20: 973-980.

[79] Grever M, Andritsos L, Banerji V, et al. Hairy cell leukemia and COVID-19 adaptation of treatment guidelines. Leukemia 2021.

[80] Tiacci E, De Carolis L, Zaja F, et al. The chemotherapy-free combination of vemurafenib and rituximab produces deep and durable responses in relapsed or refractory hairy cell leukemia (HCL) patients. Blood 2017; 130: 409.

[81] Kreitman RJ, Pastan I. Antibody fusion proteins: anti-CD22 recombinant immunotoxin moxetumomab pasudotox. Clin Cancer Res. 2011; 17: 6398-6405.

[82] Kreitman RJ, Dearden C, Zinzani PL, et al. Moxetumomab pasudotox in relapsed/refractory hairy cell leukemia. Leukemia 2018; 32: 1768-1777.

[83] Kreitman RJ, Tallman MS, Robak T, et al. Phase I trial of anti-CD22 recombinant immunotoxin moxetumomab pasudotox (CAT-8015 or HA22) in patients with hairy cell leukemia. J Clin Oncol. 2012; 30: 1822-1828.

[84] King AC, Kabel CC, Pappacena JJ, et al. No loose ends: A review of the pharmacotherapy of hairy cell and hairy cell leukemia variant. Ann Pharmacother. 2019; 53: 922-932.

[85] Andritsos LA, Grieselhuber NR, Anghelina M, et al. Trametinib for the treatment of IGHV4-34, MAP2K1-mutant variant hairy cell leukemia. Leuk Lymphoma 2018; 59: 1008-1011.

[86] Falini B, Martelli MP, Tiacci E. BRAF V600E mutation in hairy cell leukemia: from bench to bedside. Blood 2016; 128: 19181927.

[87] Maitre E, Cornet E, Troussard X. Hairy cell leukemia: 2020 update on diagnosis, risk stratification, and treatment. Am J Hematol. 2019; 94: 1413-1422.

[88] Andrasiak I, Rybka J, Wrobel T. Response to the therapy in hairy cell leukemia: Systematic review and meta-analysis. Clin Lymphoma Myeloma Leuk. 2018; 18: 392-399 e393.

A cikk a Creative Commons Attribution 4.0 International License (https://creativecommons.org/licenses/by/4.0/) feltételei szerint publikált Open Access közlemény, melynek szellemében a cikk bármilyen médiumban szabadon felhasználható, megosztható és újraközölhető, feltéve, hogy az eredeti szerző és a közlés helye, illetve a CC License linkje és az esetlegesen végrehajtott módosítások feltüntetésre kerülnek. (SID_1) 